Available online at GSC Online Press Directory

GSC Biological and Pharmaceutical Sciences

e-ISSN: 2581-3250, CODEN (USA): GBPSC2

Journal homepage: https://www.gsconlinepress.com/journals/gscbps

(RESEARCH ARTICLE)

\title{
Studies on thermodynamics and kinetics of thermo-inactivation of xylanase from salivary glands of Macrotermes subhyalinus little soldier
}

\author{
Fagbohoun Jean Bedel 1,*, Yapi Jocelyn Constant 2, Ya Kouame Claude 2, Disseka William Kwithony ${ }^{3}$, \\ Dabonne Soumaila ${ }^{3}$ and Kouame Lucien Patrice ${ }^{3}$ \\ 1 Department of Biochemistry-Genetics, University Peleforo Gon Coulibaly, Korhogo, Côte d'Ivoire \\ ${ }^{2}$ Department on Biochemestry-Microbiologie, University Lorougnon Guede, Daloa, Côte d'Ivoire \\ ${ }^{3}$ Department of Food Science and Technology, University NANGUI ABROGOUA, Abidjan, Côte d'Ivoire
}

Publication history: Received on 27 August 2020; revised on 22 September 2020; accepted on 25 September 2020

Article DOI: https://doi.org/10.30574/gscbps.2020.12.3.0279

\begin{abstract}
The effect of heat treatment on the activity of xylanase, from salivary glands of Macrotermes subhyalinus little soldier was studied over a temperature range of 50 to $70^{\circ} \mathrm{C}$ using mathematical analysis of the kinetic and thermodynamic parameters for the thermo-inactivation of the enzyme. Denaturation of the enzyme, measured by loss in activity, could be described as a first-order model, with k-values between 0.005 and 0.0217 . D-values decreased with increasing temperature, indicating faster inactivation of the enzyme at higher temperatures. Results suggested that xylanase is the rmostable with a Z-value of 22.57 , Ea of $92.68 \mathrm{~kJ} \mathrm{~mol}^{-1}$. Thermodynamic parameters were also calculated. The Gibbs free energy $(\Delta G)$, values range from 109.36 to $110.27 \mathrm{~kJ} / \mathrm{mol}$ for the enzyme. These kinetic data can be used to allow the adequate utilization of the xylanase of Macrotermes subhyalinus little soldier in the food industry and technology applications.
\end{abstract}

Keywords: Enzyme activity; Thermo-inactivation; xylanase; Kinetics; Thermodynamics; salivary glands, Macrotermes subhyalinus

\section{Introduction}

The lignocelluloses is the major constituent of the plant cell wall, it consists of lignin (15\% - 20\%), hemicellulose (25 $30 \%)$ and cellulose $(40 \%-50 \%)[1,2]$. Xylan is the most common hemicellulosic polysaccharide [3]. It is a heteropolysaccharide substituted with monosaccharides such as L-arabinose, D-galactose, D-mannoses and organic acids such as acetic acid, ferulic acid, glucuronic acid interwoven together with help of glycosidic and ester bonds [4, 5]. Xylan is a major component of hemicellulose and is a potential raw material for obtaining fermentable sugars that can be converted into several valuable products [6]. It accounts for 15\% - 30\% in hard- woods and 7\% - $10 \%$ in softwood [7]. There is a need for depolymerization of this complex polymer for its efficient utilization in different industrial application. Several xylanolytic enzymes act synergistically to hydrolyze xylan into simple monosaccharide and xylooligosac- charides completely, for example, endo-1, 4- $\beta$-xylanase, $\beta$-D-xylosidase, $\alpha$-L-arabino- furanosidases, $\alpha$ glucoronidases, and acetyl esterases [8]. Xylanases are produced by different living organisms such as microorganisms, protozoans, and molluscs, and also found in the rumen of higher animals [9]. The xylanases are mainly produced by micro- organisms, e.g., bacteria, fungi, and actinomycetes at industrial scale [4]. The utilization of lignocellulosic biomass for production of different biochemicals such as bioethanol, enzymes, and value- added compounds has tremendously improved in recent years. It results in providing opportunities for scientists to explore the hydrolytic potential of

\footnotetext{
${ }^{*}$ Corresponding author: Fagbohoun Jean Bedel

Department of Biochemistry-Genetics, University Peleforo Gon Coulibaly, Korhogo, Côte d'Ivoire.

Copyright $(2020$ Author(s) retain the copyright of this article. This article is published under the terms of the Creative Commons Attribution Liscense 4.0.
} 
xylanase for efficient saccharification of lignocellulosic biomass for ethanol and xylooligosaccharides [10]. The knowledge of xylanase opens up a wide range of biotechnological applications in multiple industries. Thus, the xylanase finds application in several industries like pulp and paper bleaching, food, feed, and pharmaceuticals. The use of xylanase in bakery break down the hemicelluloses in wheat flour, helping in the redistribution of water and leaving the dough softer and easier to knead [11]. Xylanases are commercially important because of their ability to catalyze the bioconversion of lignocellulosic material and agro- wastes into high-value products such as furfural, xylitol, biofuels, and artificial low-calorie sweeteners $[12,13]$. xylanases are being used to improve the organoleptic characteristics of the fruit juices [14]. The use of xylanases in various production processes may reduce the use of chemical additives such as bromates [15]. Xylanases together with pectinases are commonly used for degumming of bast fibers such as flax, hemp, jute, and ramie [16]. In the brewing industry, addition of xylanase to brewery mash significantly reduces the filtration rate and viscosity [17]. Based on the importance of xylanases offer over conventional chemical reagents, their application at an industrial scale, they must be required in huge amount for industrial level application with characteristic properties to survive the harsh industrial level processing's [17]. Therefore, there is a need to select potent microorgan- isms for xylanase production, followed by optimization of media components for enhanced production, to know optimal conditions of enzyme active sites functioning and the effect of different physical-chemical factors on their activity. The aim of this work was to investigate the effect of heat treatment over a range of temperatures from 50 to $70{ }^{\circ} \mathrm{C}$ on the xylanase. So, determination and analysis of kinetic and thermodynamic parameters were undertaken. These results can indicate an adequate choice of temperature conditions to use of xylanase, from salivary glands of Macrotermes subhyalinus little soldie in industries and allow to predict the impact of a given heat-treatment and to design processes suitable to obtain the desired product properties [18].

\section{Material and methods}

\subsection{Enzyme source}

Xylanase used in this study were previously purified from salivary glands of Macrotermes subhyalinus little soldier [19, 20]. This enzyme were homogeneous on polyacrylamide-gel electrophoresis without sodium dodecyl sulphate (SDS).

\subsection{Enzyme assay and protein determination}

Under the standard test conditions, xylanase activity was assayed spectrophotometrically by measuring the release of reducing sugars from Birchwood xylan. The reaction mixture $(0.38 \mathrm{ml})$ contained $0.2 \mathrm{ml}$ of $0.5 \%$ xylan (w/v) dissolved in $20 \mathrm{mM}$ acetate buffer (pH 5.0) and $0.1 \mathrm{ml}$ enzyme solution. After $30 \mathrm{~min}$ of incubation at $45^{\circ} \mathrm{C}$, the reaction was stopped by adding $0.3 \mathrm{ml}$ of dinitrosalicylic acid solution and heating for $5 \mathrm{~min}$ in boiling water bath. The absorbance was measured at $540 \mathrm{~nm}$ after cooling on ice for $5 \mathrm{~min}$. Experiments were performed in triplicate, and the specific activity was expressed as units per $\mathrm{mg}$ of protein (U/mg of protein). One unit (U) of enzyme activity was defined as the amount of enzyme capable of releasing one $\mu \mathrm{mol}$ of reducing sugar per min under the defined reaction conditions. Protein was determined by the method of Lowry [21] using bovine serum albumin as standard.

\subsection{Thermal inactivation}

The thermal inactivation of the enzyme was determined at constant temperature between 50 and $70{ }^{\circ} \mathrm{C}$ after exposure to each temperature for a period of 5 to $60 \mathrm{~min}$. The enzyme was heated in sealed tubes, which was incubated in 100 mM sodium acetate buffer ( $\mathrm{pH}$ 5.0) in a thermostatically controlled water bath. Tubes were withdrawn at each time intervals and immediately immersed in an ice bath, in order to stop heat inactivation. The residual enzymatic activity, determined at $37{ }^{\circ} \mathrm{C}$ under the standard test conditions, was expressed as percentage activity of zero-time control of the untreated enzyme.

\subsection{Kinetic data analysis}

First-order kinetic has been reported to describe thermal inactivation of xylanase [22]. The integral effect of inactivation process at constant temperature, where the inactivation rate constant is independent of time, is given in Equation 1 (Eq. 1). nge:

$\ln (\mathrm{At} / \mathrm{A} 0)=-\mathrm{kt}$

where, At is the residual enzyme activity at time $\mathrm{t}(\mathrm{min})$, Ao is the initial enzyme activity, $\mathrm{k}\left(\mathrm{min}^{-1}\right)$ is the inactivation rate constant at a given condition. $\mathrm{k}$-values were obtained from the regression line of ln (At/Ao) versus time as slope. 
D-value is defined as the time needed, at a constant temperature, to reduce the initial enzyme activity (Ao) by $90 \%$. For first-order reactions, the D-value is directly related to the rate constant k (Eq. 2) [23, 24]:

$\mathrm{D}=2.303 / \mathrm{k}$

The Z-value $\left({ }^{\circ} \mathrm{C}\right)$ is the temperature increase needed to induce a 10 -fold reduction in D-value [23] and follows the Eq. 3:

$\log (\mathrm{D} 1 / \mathrm{D} 2)=(\mathrm{T} 2-\mathrm{T} 1) / \mathrm{Z}$

where, T1 and T2 are the lower and higher temperatures in ${ }^{\circ} \mathrm{C}$ or $\mathrm{K}, \mathrm{D} 1$ and $\mathrm{D} 2$ are D-values at the lower and higher temperatures in min, respectively.

The Z-values were determined from the linear regression of $\log (\mathrm{D})$ and temperature (T).

\subsection{Thermodynamic analysis}

The Arrhenius equation is usually utilized to describe the temperature effect on the inactivation rate constants and the dependence is given by (Eq. 4 or 5): Actvation energy (Ea)

$\mathrm{k}=\mathrm{Aexp}(-\mathrm{Ea} / \mathrm{RT})$

or $\ln \mathrm{k}=\ln \mathrm{A}-(\mathrm{Ea} / \mathrm{RT})$

where, $\mathrm{k}$ is the reaction rate constant value, $A$ the Arrhenius constant, Ea (kJ.mol ${ }^{-1}$ ) the activation energy, $\mathrm{R}\left(8.31\right.$ J.mol ${ }^{-}$ $1_{\mathrm{K}^{-1}}$ ) the universal gas constant and $\mathrm{T}(\mathrm{K})$ the absolute temperature.

When lnk is plotted versus the reciprocal of the absolute temperature, a linear relationship should be observed in the temperature range studied. The slope of the line obtained permitted to calculate the Ea and the ordinate intercept corresponds to $\ln \mathrm{A}[25]$. The changes in enthalpy $\left(\Delta \mathrm{H}^{\#}, \mathrm{~kJ} \cdot \mathrm{mol}^{-1}\right)$, entropy $\left(\Delta \mathrm{S}^{\#}, \mathrm{~J} \cdot \mathrm{mol}^{-1} \cdot \mathrm{K}^{-1}\right)$ and Gibbs free energy $\left(\Delta \mathrm{G}^{\#}\right.$, $\mathrm{kJ} \cdot \mathrm{mol}^{-1}$ ) for the thermal denaturation of xylanase were determined using following equations (Eq. 6; 7; 8) [26].

$\Delta \mathrm{H}^{\#}=\mathrm{Ea}-\mathrm{RT}$

$\Delta \mathrm{S}^{\#}=\mathrm{R}\left(\ln \mathrm{A}-\ln \mathrm{K}_{\mathrm{B}} / \mathrm{h}_{\mathrm{p}}-\ln \mathrm{T}\right)$

$\Delta \mathrm{G}^{\#}=\Delta \mathrm{H}^{\#}-\mathrm{T} \Delta \mathrm{S}^{\#}$

where, $\mathrm{K}_{\text {в }}\left(1.38 \times 10^{-23} \mathrm{~J} . \mathrm{K}^{-1}\right)$ is the Boltzmann's constant, $\mathrm{h}_{\mathrm{p}}$ the Planck's constant $\left(6.626 \times 10^{-34} \mathrm{~J} . \mathrm{s}\right)$ and T the absolute temperature.

\subsection{Statistical analyses}

All determinations reported in this study were carried out in triplicate. Results were expressed as means \pm standard deviation.

\section{Results and discussion}

Fagbohoun and Fagbohoun [19, 20]. have purified a xylanase from salivary glands of Macrotermes subhyalinus little soldier. Thus, enzyme showed maximal hydrolytic activitie at $50{ }^{\circ} \mathrm{C}$. The rate of thermal inactivation of xylanase was measured over the temperature range $50{ }^{\circ} \mathrm{C}-70{ }^{\circ} \mathrm{C}$. It was observed that the time and temperature of the heating process affected the rate of inactivation of the enzyme. The residual enzyme activities for xylanase is shown in Table 1 . The enzyme is completely inactivated between $65^{\circ} \mathrm{C}$ and $70^{\circ} \mathrm{C}$ after 35 minutes (Table 1). It is well known that enzymes are proteins with three-dimensional structure which are essential for their activities [27]. It seems that after a long-term exposure to heat, this enzyme three-dimensional structure was destabilized and then, inactivated. So, a biocatalyst capable to resist against thermal unfolding in absence of substrate is categorized as thermostable, while an enzyme molecule able to catalyze reactions (that means substrate presence) at high temperatures (beyond $70{ }^{\circ} \mathrm{C}$ ) is qualified of thermophilic [28]. 
Table 1 Effect of treatment temperature and time on the inactivation of xylanase from salivary glands of Macrotermes subhyalinus little soldier.

\begin{tabular}{|c|c|c|c|c|c|}
\hline \multirow{2}{*}{$\begin{array}{l}\text { Relative activity } \\
\text { (\%) at each } \\
\text { treatment time } \\
\text { (min) }\end{array}$} & \multicolumn{5}{|c|}{ Temperature $\left({ }^{\circ} \mathrm{C}\right)$} \\
\hline & $\mathbf{5 0}$ & 55 & 60 & 65 & 70 \\
\hline $5 *$ & $97.53 \pm 0.8$ & $95.12 \pm 0.6$ & $91.39 \pm 0.7$ & $90.48 \pm 0.8$ & $69.76 \pm 0.7$ \\
\hline 10 & $95.95 \pm 1.9$ & $92.31 \pm 0.9$ & $86.07 \pm 1.0$ & $81.05 \pm 1.6$ & $49.65 \pm 1.5$ \\
\hline 15 & $92.31 \pm 1.0$ & $88.69 \pm 0.4$ & $77.88 \pm 0.4$ & $74.08 \pm 0.2$ & $27.25 \pm 0.6$ \\
\hline 20 & $90.48 \pm 0.9$ & $86.07 \pm 0.4$ & $74.08 \pm 0.8$ & $67.03 \pm 1.3$ & $20.18 \pm 0.8$ \\
\hline 25 & $87.80 \pm 0.6$ & $81.87 \pm 0.2$ & $70.46 \pm 1.0$ & $57.89 \pm 0.5$ & $13.53 \pm 0.8$ \\
\hline 30 & $86.07 \pm 1.1$ & $79.45 \pm 0.6$ & $65.05 \pm 0.4$ & $52.89 \pm 0.2$ & $8.20 \pm 0.3$ \\
\hline 35 & $83.83 \pm 0.0$ & $77.38 \pm 0.3$ & $58.86 \pm 0.4$ & $45.84 \pm 0.2$ & 0 \\
\hline 40 & $81.87 \pm 0.4$ & $74.08 \pm 0.7$ & $54.88 \pm 0.7$ & $41.89 \pm 0.5$ & 0 \\
\hline 45 & $80.25 \pm 0.1$ & $71.89 \pm 0.7$ & $49.65 \pm 1.1$ & $37.53 \pm 1.0$ & 0 \\
\hline 50 & $78.38 \pm 0.2$ & $69.07 \pm 0.2$ & $47.23 \pm 0.3$ & $33.28 \pm 0.6$ & 0 \\
\hline 55 & $76.03 \pm 0.4$ & $67.03 \pm 0.7$ & $44.93 \pm 0.5$ & $30.11 \pm 0.9$ & 0 \\
\hline 60 & $74.08 \pm 0.3$ & $63.76 \pm 0.2$ & $39.45 \pm 0.3$ & $27.25 \pm 0.6$ & 0 \\
\hline
\end{tabular}

The thermal inactivation of the xylanase studied represented in Figure 1 shows that the enzyme followed a first-order kinetic. This is explained by the logarithmic linear relationship between the xylanase activities and time of treatment for the temperatures ranged from $50{ }^{\circ} \mathrm{C}$ to $70{ }^{\circ} \mathrm{C}$ (Fig. 1). Similar results have been reported for xylanase from the thermophilic fungus Melanocarpus albomyces [29]. Moreover, this linear appearance for the graph ln (At /A0) suggests that each reaction mixture contains only one enzyme that catalyzes the substrate hydrolysis. Indeed, the combined activities of several xylanases (in the same reaction mixture) would have resulted in a curve with many phases instead of a straight line.

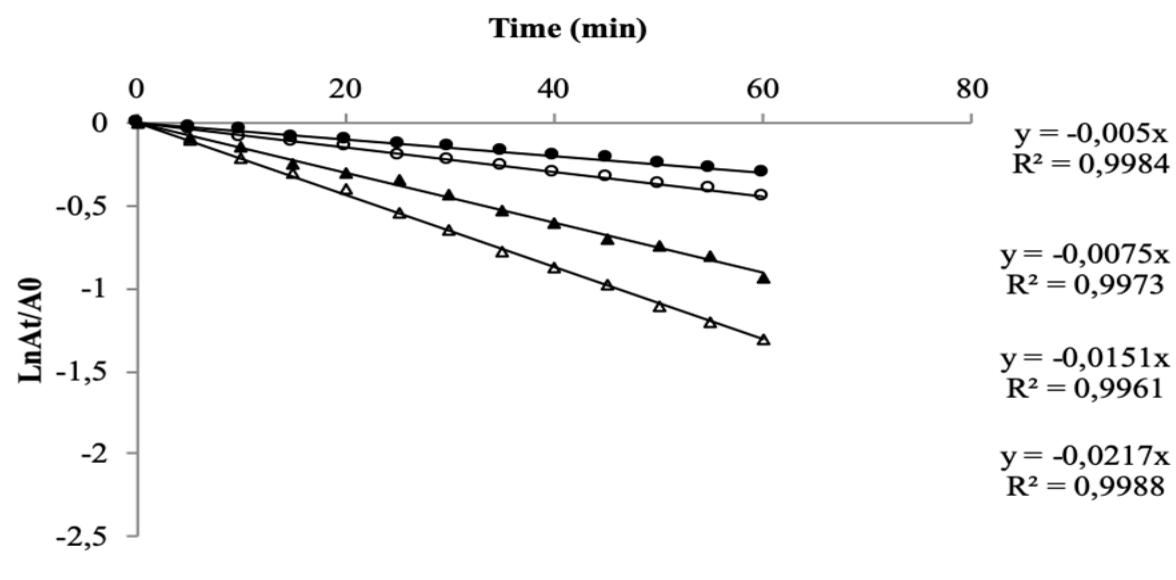

(O) $50^{\circ} \mathrm{C} ;(0) 55^{\circ} \mathrm{C} ;(\mathbf{\Delta}) 60^{\circ} \mathrm{C} ;(\Delta) 65^{\circ} \mathrm{C}$.

Figure 1 First order thermal inactivation of xylanase isolated from salivary glands of Macrotermes subhyalinus little soldier at different temperature. A0 is the initial enzymatic activity and At the activity at each holding time. Each data point is the mean of three determinations

From the slope of the graphs in Figure 2, the inactivation rate constants (k) were estimated. Then, k values and half-life $(\mathrm{t} 1 / 2)$ of studied xylanase is presented in Table 2. These results show that $\mathrm{k}$ values increase with increasing pre- 
incubation temperature for the enzyme. This confirms the instability of the enzymatic protein at high temperatures as reported by [30]. This author argues that higher value of k constant means that the enzyme was less thermostable. As concerned the half-life of xylanase from salivary glands of Macrotermes subhyalinus little soldier, she appear to be too longer at optimum temperature, then she decrease beyond. At the optimum temperature, xylanase showed half-live of 138.60 minutes. This result suggests that xylanase isolated from salivary glands of Macrotermes subhyalinus little soldier more thermally stable. However, the half-live found in this study was higher compared to half-life obtained for xylanase from the fungus Melanocarpus albomyces IIS 68 which was of 126.1 minutes at $50^{\circ} \mathrm{C}$ [29].

Table 2 k, D-, t1/2, Z- and Ea-values for thermal inactivation of xylanase from salivary glands of Macrotermes subhyalinus little soldier. in the $50-65{ }^{\circ} \mathrm{C}$ temperature range.

\begin{tabular}{|c|c|c|c|c|c|c|}
\hline \multirow{3}{*}{ Temperature $\left({ }^{\circ} \mathrm{C}\right)$} & \multicolumn{6}{|c|}{ Kinetic parameters } \\
\hline & \multicolumn{2}{|l|}{$\mathrm{K}\left(\mathrm{min}^{-1}\right)$} & \multirow[t]{2}{*}{ D (min) } & \multirow[t]{2}{*}{$t_{1 / 2}(\min )$} & \multirow[t]{2}{*}{$\mathrm{Z}\left({ }^{\circ} \mathrm{C}\right)$} & \multirow[t]{2}{*}{ Ea $(\mathrm{kJ} / \mathrm{mol})$} \\
\hline & Value & $\mathbf{R}^{2}$ & & & & \\
\hline 50 & $0.005 \pm 0.001 \mathrm{a}$ & 0.998 & $460.6 \pm 35$ & $138.60 \pm 7$ & & \\
\hline 55 & $0.0075 \pm 0.002$ & 0.997 & $307.06 \pm 27$ & $92.40 \pm 6$ & $22.57 \pm 0.4$ & $92.68 \pm 0.26$ \\
\hline 60 & $0.0151 \pm 0.001$ & 0.996 & $152.51 \pm 25$ & $45.89 \pm 3$ & & \\
\hline 65 & $0.0217 \pm 0.001$ & 0.998 & $106.12 \pm 27$ & $31.93 \pm 5$ & & \\
\hline
\end{tabular}

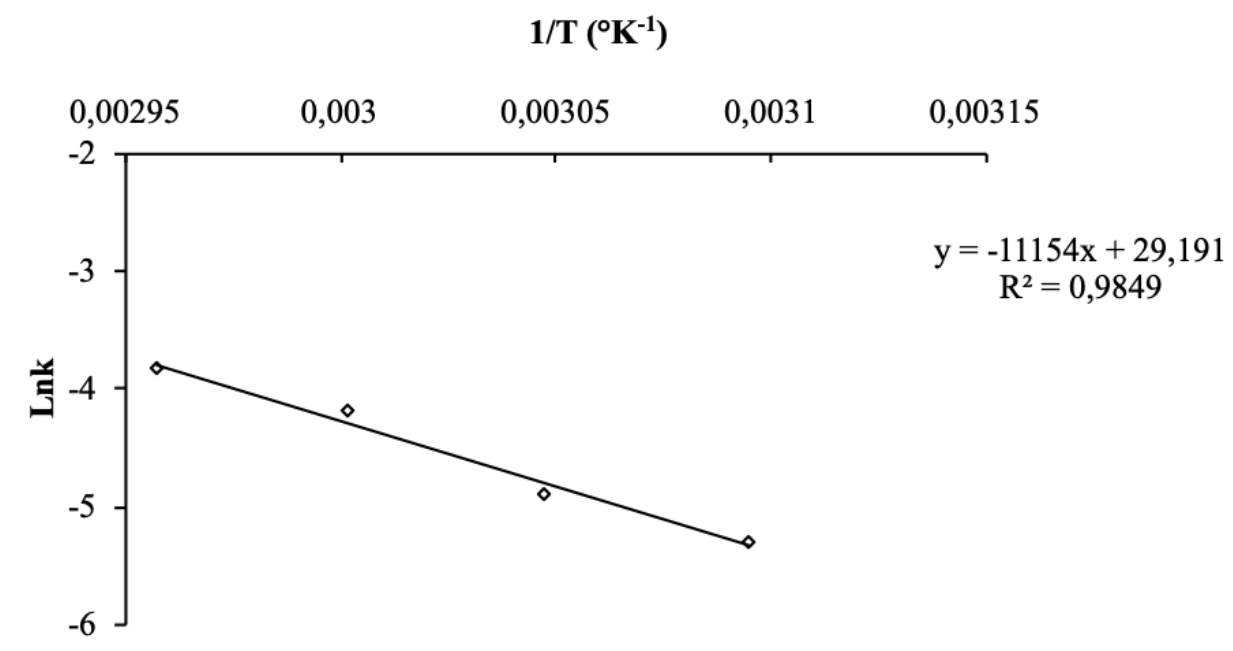

Figure 2 Arrhenius plot for thermal inactivation of xylanase isolated from salivary glands of Macrotermes subhyalinus little soldier. 1/T represents the reciprocal of the absolute temperature. Each data point is the mean of three determinations

Figure 3 depicts the effect of temperature on $\mathrm{D}$ values for inactivation of the xylanase isolated from salivary glands of Macrotermes subhyalinus. The D values, which are the time required to reduce the enzyme activities by $90 \%$, corroborate results obtained for half-life. Indeed, for the studied xylanase, D values decreased very sharply with increasing temperature. This is the proof that the inactivation time of the studied enzymatic molecule is shortened rapidly at high temperatures.

Similarly to the works of Bankeeree et al. [31] thermal stability of tropical isolate xylanase from Aureobasidium pullulans, purified xylanase from Aspergillus niger DFR-5 and peptide P34 decreased respectively at higher temperature. D-values for xylanase ranged from $460.6 \pm 2.78$ to $106.12 \pm 0.68 \mathrm{~min}$. The effect of temperature on D- and Z-values of xylanase from little soldier of Macrotermes subhyalinus are shown in Table 3.

The temperature increase required to decrease the D- value by one log cycle i.e. Z-value, of the xylanase, calculated from the slope of graph between log D versus temperature, was $22.57 \pm 3.02$ (Figure 3). The high magnitudes of Z-values mean more sensitivity to the duration of heat treatment and lower Z-values mean more sensitivity to increase temperature [32]. In fact, differences between the D- and Z- values of enzyme and nutrients are exploited to optimize 
thermal processes and can be exploited also to maintain xylanases activity after treatment. In this study, D-, Z- and kvalues indicate that the xylanase are heat stable and then can be used in high temperature short time and low temperature long time industrial processes such as pasteurization, where values of $65^{\circ} \mathrm{C}$ for $3-5$ min and $55{ }^{\circ} \mathrm{C}$ for 30 min, respectively, are generally considered. In fact the D- and Z-values of xylanase are exploited to optimize thermal processes and to preserve enzyme activity after treatment.

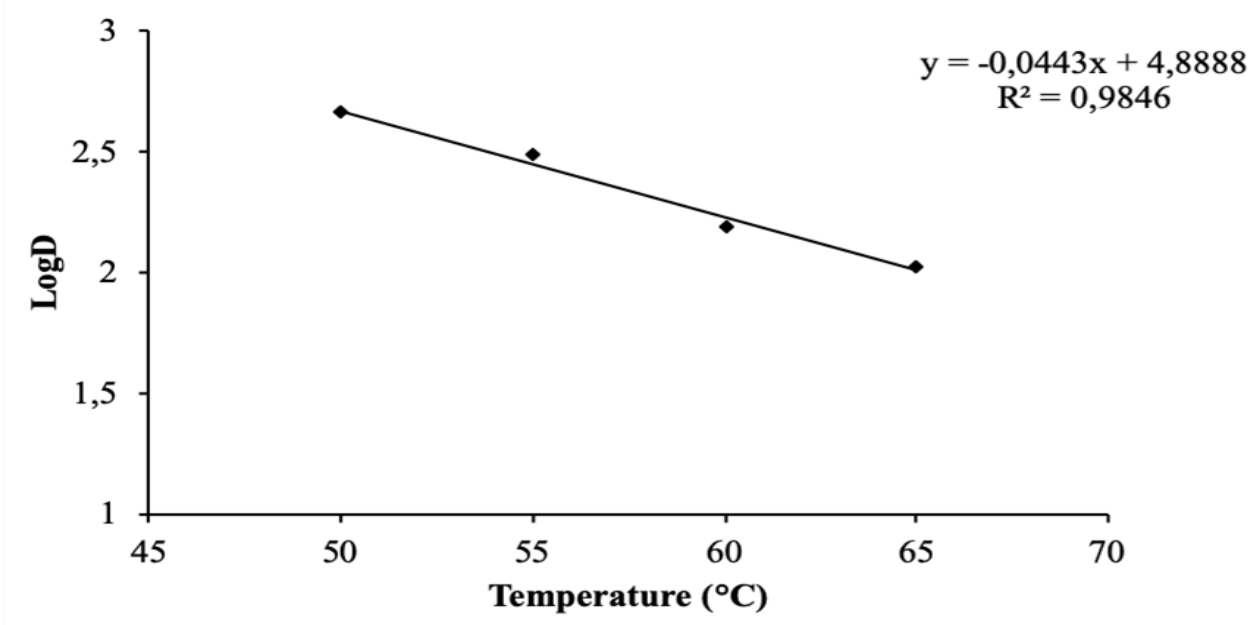

Figure 3 Effect of temperature on D values for inactivation of xylanase isolated from salivary glands of Macrotermes subhyalinus little soldier. Each data point is the mean of three determinations

The slopes of Arrhenius plots in Figure 2 allow us to calculate the activation energy (Ea) of the enzyme. Activation energy is a minimum amount of energy required for the native enzyme in order to initiate the inactivation or denaturation process. This activation energy can be seen as the energy barrier that molecules need to cross to be able to react [33]. Beyond the activation energy, the enzyme is denatured and cannot refold to the native form as reported by Siddiqui et al. [34]. The Ea value of xylanase from little soldier of Macrotermes subhyalinus was from $92.68 \mathrm{~kJ} / \mathrm{mol}$ (Table 2). For example, it means that for xylanase, it was necessary to absorb $92.68 \mathrm{~kJ}$ from the external medium to start its inactivation at temperatures between $50{ }^{\circ} \mathrm{C}$ and $70^{\circ} \mathrm{C}$. This value was lower than the one found $(108.69 \mathrm{~kJ} / \mathrm{mol})$ for endoglucanase from Humicola insolens [35]. The relative high value obtained for activation energie suggest that important energy amounts must be supplied to the studied enzyme in order to initiate the denaturation process. It means that the xylanase is relatively thermostable.

The activation energy value enabled the determination of enthalpy, entropy, and free energy of activation of the enzyme. These thermodynamic parameters of inactivation provides information on the enzyme thermal stability for each step of the heat-induced denaturation process. This could help in detecting any secondary stabilization or destabilization effects that would go unnoticed if only the half-life times were considered [36].These parameters include $\Delta \mathrm{G}$, the Gibbs free energy change considered as the energy barrier for enzyme inactivation, the enthalpy $(\Delta H)$ change measuring of the number of bonds broken during inactivation, and the entropy $(\Delta S)$ change that indicates the net enzyme and solvent disorder. They were calculated in the temperature range 50 to $70{ }^{\circ} \mathrm{C}$ from experimental data using eqs $6-8$ (Table 3 ). Results for $\Delta \mathrm{H}$ show that, within the error range of our measurements, the enthalpy is independent of temperature; thus, there is no change in the enzyme heat capacity (Table 3 ). The $\Delta \mathrm{H}$ value found in this study (89.94 $\mathrm{kJ} / \mathrm{mol}$ ) was much higher than those reported for other xylanases (Xyl1 and Xyl2), from abdomen of Macrotermes subhyalinus little soldier (45.34 and $72.77 \mathrm{~kJ} / \mathrm{mol}$ ) [37]. In general, $\Delta \mathrm{H}$ is seen as a measure of the number of noncovalent bonds broken in forming a transition state for enzyme inactivation. Therefore, the higher the $\Delta \mathrm{H}$ is, the larger will be the number of noncovalent bonds present in the enzyme molecule, which is going to be more stable. In fact, the stability of a protein is the result of a delicate balance between stabilizing and destabilizing forces, which may be influenced by several factors, e.g., the number of hydrogen and disulfide bridges, the folding degree and hydrophobicity of the molecule, and the amount of ionic and other interactions [38]. Our results would therefore suggest that xylanase, from salivary glands of Macrotermes subhyalinus little soldier is more structurally robust than the others enzymes. However, Forsyth et al. [39] raised questions about the suitability of use of isolated $\Delta \mathrm{H}$ values as indicators of enzyme stability.

In contrast, the $\Delta \mathrm{G}$ value is directly related to protein stability: the higher the $\Delta \mathrm{G}$ is, the higher will be the enzyme stability. When the incubation temperature was elevated from 50 to $70{ }^{\circ} \mathrm{C}$, there was a slightly increase of $\Delta \mathrm{G}$ values for the xylanase, from salivary glands from $109.36 \mathrm{~kJ} / \mathrm{mol}$ to $110.27 \mathrm{~kJ} / \mathrm{mol}$ (Table 3), indicating that the inactivation 
processes were not spontaneous. Since $\Delta \mathrm{G}$ decreases with increasing temperature whereas $\Delta H$ is overall constant, one could expect a significant contribution of entropy changes to the thermodynamics of the considered system. In fact, it was already demonstrated that activation entropy has a dominant role in thermal inactivation of proteins in aqueous solutions $[39,40]$.

As indicated in Table 3, all $\Delta \mathrm{S}$ values for thermal inactivation of the xylanase, from salivary glands of Macrotermes subhyalinus little soldier are negative and similar $(-60.17 \mathrm{~J} / \mathrm{mol} \bullet \mathrm{K})$ in the temperature range 50 to $70^{\circ} \mathrm{C}$. This suggests that there are no significant processes of aggregation, since, if this would happen, the values of entropy would be positive [41]. The most common cause of the heat inactivation of enzymes is the loss of the native conformation (unfolding of the active tertiary protein structure to a disordered polypeptide), a process identified as thermodenaturation, which takes place as a result of increased molecular mobility at elevated temperature [42].

Based on our results, it is concluded that thermal inactivation of the xylanase, from salivary glands of Macrotermes subhyalinus little soldier could be described by a firs-order kinetic model. D-, Z-, k values and the high values obtained for activation energy and change in enthalpy indicated that a high amount of energy was needed to initiate denaturation of the xylanase from Macrotermes subhyalinus little soldier, most likely due to its stable molecular conformation. This high thermostability may be taken into account when thermal treatments are used to obtain processed products derived from the xylanase, from salivary glands of Macrotermes subhyalinus little soldier.

\section{Conclusion}

Analysis of the inactivation constants during the heat treatment showed that the xylanasic activity of the small soldier of the termite Macrotermes subhyalinus decreases according to kinetics of order 1 . The values of the parameters D and $\mathrm{Z}$ show that these enzymes reflect resistance and thermal stability over time. The thermotolerance of these biocatalysts is confirmed by the high values of activation energy and free enthalpy. xynalase is of major importance in various commercial processes, particularly in the stationery industry and in the food industry. Much thought has been given to the use of xylanase to improve the degradation of biomass for biofuels. Exploration of the hydrolytic and thermodynamic potential of xylanase isolated from the termite Macrotermes subhyalinus is an excellent lead for potential use in biofuel production. Because indeed, these termites feed only on vegetable matter which is among other things the subsrat for the production of biofuels.

\section{Compliance with ethical standards}

\section{Disclosure of conflict of interest}

Authors declare that they have no any conflict of interest.

\section{References}

[1] Gray KA, Zhao L, Emptage M. Current opinion in chemical biology. Bioethanol Curr Opin Chem Biol. 2006; 10: 141-146.

[2] Singla A, Paroda S, Dhamija SS. Bioethanol production from xylose: problems and possibilities. J Biofuels. 2012; 3: 1-17.

[3] Collins T, Gerday C, Feller G. Xylanases, xylanase families and extremo- philic xylanases. FEMS Microbiol Rev. 2005; 29: 3-23.

[4] Motta FL, Andrade CCP, Santana MHA. A review of xylanase production by the fermentation of xylan: Classification, characterization and applications. 2013.

[5] Sharma PK. Xylanases current and future perspectives : a review Pawan Kumar Sharma. New Biol Rep. 2017; 6: 122.

[6] Malhotra G, Chapadgaonkar SS.Production and applications of xylanases - an overview, Journal of Biotechnology, Computational Biology and Bionanotechnology. 2018; 99(1): 59-72.

[7] Walia A, Guleria S, Mehta P, Chauhan A, Parkash J. Microbial xylanases and their industrial application in pulp and paper biobleaching: a review. 3 Biotech. 2017; 7: 1-12. 
[8] Poutanen K, Ratto M, Puls J, Viikari L. Evaluation of different microbial xylanolytic systems. J. Biotech. 1987; 6: 49-60.

[9] Beg Q, Kapoor M, Mahajan L, Hoondal GS. Microbial xylanases and their industrial applications: a review. Appl Microbiol Biotechnol. 2001; 56: 326-338.

[10] Bhardwaj N, Kumar B, Verma P. A detailed overview of xylanases: an emerging biomolecule for current and future prospective. Bioresources and Bioprocessing. 2019; 6: 1-40.

[11] Butt MS, Tahir-Nadeem M, Ahmad Z, Sultan MT. Xylanases and their applications in baking industry. Food Technol Biotechnol. 2008; 46: 22-31.

[12] Polizeli MLTM, Rizzatti ACS, Monti R, Terenzi HF, Jorge JA, Amorim DS. Xylanases from fungi: pro- perties and industrial applications. Appl. Microbiol. Bio- technol. 2005; 67: 577-591.

[13] Parajò JC, Domínguez H, Domínguez J. Biotechno- logical production of xylitol. Part 1: Interest of xylitol and fundamentals of its biosynthesis. Biores Technol. 1998; 65: 191-201.

[14] Kumar L, Nagar S, Mittal A et al. Immobilization of xylanase purified from Bacillus pumilus VLK-1 and its application in enrichment of orange and grape juices. J Food Sci Technol. 2014; 51: 1737-1749.

[15] Kulkarni N, Shendye A, Rao M. Molecular and bio- technological aspects of xylanases. FEMS. Microbiol. Rev. 1999; 23: 411-456.

[16] Paridah MT, Basher AB, Saiful Azry S, Ahmed Z. Retting process of some bast plant fibers and its effect on fiber quality: A review. BioResources. 2011; 6(4): 5260-5281.

[17] Qiu Z, Shi P, Luo H et al. A xylanase with broad pH and temperature adaptability from Streptomyces megasporus DSM 41476, and its potential application in brewing industry. Enzyme Microb Technol. 2010; 46: 506-512.

[18] Van Loey A, Smout C, Indrawati \& Hendrickx M. Kinetic data for biochemical and microbiological processes during thermal processing. In M. A. Rao, S. S. H. Rizvi, \& A. K. Datta (Eds.), Engineering properties of foods. 2005; 611-643.

[19] Fagbohoun JB, Ahi AP, Karamoko Y, Dabonné S, Kouadio EJP, Kouamé LP. An endo- beta-D-glycosidase from salivary glands of Macrotermes subhyalinus little soldier with a dual activity against carboxymethylcellulose and xylan. International Journal of Biosciences. 2012; 2: 1-10.

[20] Fagbohoun JB. Propriétés biochimiques, analyses cinétique et thermodynamique des enzymes responsables de la cellulolyse et de la xylanolyse chez le petit soldat du termite Macrotermes subhyalinus (Termitidae, Macrotermitinae). Ph.D. Thesis, Université Nangui Abrogoua, Abidjan, Côte d'Ivoire. 2013.

[21] Lowry OH, Rosebrough NJ, Farra L, Randall RJ. Protein measurement with Folin phenol reagent. J Biol Chem. 1951;193: 265-75.

[22] Guiavarc'h YP, Deli V, Van Loey AM, Hendrickx ME. Development of anenzymic time temperature integrator forsterilization processes based on Bacillus licheniformis alpha-amylase at reduced water content. Journal of Food Science. 2002; 67(1): 285-291.

[23] Stumbo CR. Thermobacteriology in food processing (2nd ed). New York: Academic Press. $1973 ; 336$.

[24] Espachs-Barroso A, Loey AV, Hendrickx, M, Martín-Belloso O. Inactivation of plant pectin methylesteraseby thermal or high intensity pulsed electric field treatments. Innovative Food Science and Emerging Technologies. 2006; 7: 40-48.

[25] Dogan M, Arslan 0, Dogan S. Substrate specificity, heat inactivation and inhibition of polyphenol oxidase from different aubergine cultivars. Int. J. Food Sci. Technol. 2002; 37: 415-423.

[26] Gummadi SN. What is the role of thermodynamics in protein stability? Biotechnology Bioprocess Engineery. 2003; 8: 9 - 18 .

[27] Petsko GA, Ringe D. Protein structure and function. New Science Press in Association with Sinauer Associates and Blackwell Science, London, UK. 2004; 45.

[28] Georis J, De Lemos Esteves F, Lamotte-Brasseur J, Bougnet V, Devreese B, Giannotta F. An additional aromatic interaction improves the thermostability and thermophilicity of a mesophilic family 11 xylanase: structural basis and molecular study. Protein Sci. 2000; 9(3): 466-75. 
[29] Gupta G, Sahai V, Gupta RK. Thermal Stability and Thermodynamics of Xylanase from Melanocarpus albomyces in Presence of Polyols and Salts, BioResources. 2014; 9(4): 5801-5816.

[30] Marangoni AG. Characterization of enzyme stability. In: Enzyme kinetics: a modern approach, John Wiley \& Sons, Inc., Hoboken, NJ. 2003.

[31] Bankeeree W, Lotrakul P, Prasongsuk S, Chaiareekij S, Eveleigh DE, Kim SW, Hunsa Punnapayak. Effect of polyols on thermostability of xylanase from a tropical isolate of Aureobasidium pullulans and its application in prebleaching of rice straw pulp. Springer Open Journal. 2014; 3: 37.

[32] Tayefi-Nasrabadi H, Asadpour R. Effect of heat treatment on buffalo (Bubalus bubalis) lactoperoxidase activity in raw milk. Journal of Biology Science. 2008; 8(8): 1310-1315.

[33] Yan J, Pan G, Ding C, Quan G. Kinetic and thermodynamic parameters of $\beta$-glucosidase immobilized on various colloidal particles from a paddy soil. Colloids Surf B: Biointerfaces. 2010; 79: 298-303.

[34] Siddiqui KS, Azhar MJ, Rashid MH, Rajoka MI. Stability and identification of active-site residues of carboxymethylcellulases from Aspergillus niger and Cellulomonas biazotea. Folia Microbiol. 1997; 42(4): 312-8.

[35] Riaz H, Jabbar A, Rashid MH, Riaz S, Latif F. Endoglucanase production by Humicola insolens: effect of physiochemical factors on growth kinetics and thermodynamics. International Journal Of Agriculture and Biology. 2014; 16(6): 1141-146.

[36] Longo MA, Combes D. Thermostability of modified enzymes -a detailed study. J. Chem. Technol. Biotechnol. 1999; 74: 25-32.

[37] Fagbohoun JB, Gnanwa MJ, Detto Karamoko D, Zan TEB, Dabonne S, Kouame PL. Thermal stability of two xylanases from Macrotermes subhyalinus little soldier: kinetic and thermodynamic analysis. International Journal of Biosciences. 2018; 12(1): 65-75.

[38] Bruins ME, Janssen AEM, Boom RM. Thermozymes and their applications. Appl. Biochem. Biotechnol. 2001; 90(32): 155-181.

[39] Forsyth JL, Apenten RKO, Robinson DS. The thermostability of purified peroxidases from Brassica oleracea var. gemmifera. Food Chem. 1999; 65: 99-109.

[40] Bromberg A, Marx S, Frishman G. Kinetic study of the thermal inactivation of cholinesterase enzymes immobilized in solid matrices. Biochim. Biophys. Acta. 2008; 1784: 961-966.

[41] Anema SG, McKenna AB. Reaction kinetics of thermal denaturation of whey proteins in heated reconstituted whole milk. Journal of Agricultural and Food Chemistry. 1996; 44(2), 422-428. 